\title{
Post-cryopreservation viability of the benthic freshwater diatom Planothidium frequentissimum depends on light levels ${ }^{\text {is }}$
}

\author{
Matthias T. Buhmann ${ }^{\mathrm{a}, 1}$, John G. Day ${ }^{\mathrm{b}, *}$, Peter G. Kroth ${ }^{\mathrm{a}}$

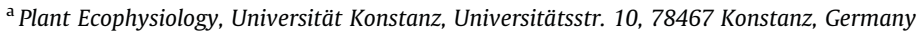 \\ ${ }^{\mathrm{b}}$ Culture Collection of Algae and Protozoa, Scottish Association for Marine Science, Scottish Marine Institute, Oban, Argyll PA37 1QA, UK
}

\begin{abstract}
A B S T R A C T
Over recent years, several planktonic and benthic freshwater diatom taxa have been established as lab oratory model strains. In common with most freshwater diatoms the pennate diatom Planothidium fre quentissimum suffers irreversible cell shrinkage on prolonged maintenance by serial transfers, without induction of the sexual cycle. Therefore, alternative strategies are required for the long term maintenance of this strain. Conventional colligative cryopreservation approaches have previously proven unsuccessful with no regrowth. However, in this study using $5 \%$ dimethyl sulfoxide $\left(\mathrm{Me}_{2} \mathrm{SO}\right)$, controlled cooling at $1{ }^{\circ} \mathrm{C} \mathrm{min}-1$, automated ice seeding and cooling to $-40{ }^{\circ} \mathrm{C}$ with a final plunge into liquid nitrogen, viability levels were enhanced from $0.3 \pm 0.4 \%$ to $80 \pm 3 \%$, by incorporating a $48 \mathrm{~h}$ dark recovery phase after rewarming. Omission, or reduction, of this recovery step resulted in obvious cell damage with photo bleaching of pigments, indicative of oxidative stress induced cell damage, with subsequent deterioration of cellular architecture.

\section{Introduction}

Diatoms are of great ecological significance and can be found globally in almost all freshwater and marine ecosystems, com monly representing one of the main components of the phyto plankton [25]. Their ecological roles and diversity are reflected in their biodiversity and the number of species has been estimated to be more than $10^{5}$ [20], but could potentially be much greater. Diatoms have significant biotechnological potential as many taxa produce high levels of lipids, including high levels of triacylglyce rols, making them candidates for aquaculture feeds, functional foods and even as a potential feedstock for biodiesel [26,21]. Furthermore, in phycology there has recently been particular emphasis on the utilization of "model" organisms, particularly in the case of lab based studies, with an increasing focus on "genomic

\footnotetext{
Abbreviations: $\mathrm{Me}_{2} \mathrm{SO}$, dimethyl sulfoxide; CFSE, carboxy fluorescein succinimidyl ester; FDA, fluorescein diacetate; ROS, reactive oxygen species.

This work was supported by the European Commission (ASSEMBLE, Integrated Infrastructures Initiative, grant agreement no. 227799), the UK Natural Environment Research Council (National Capability funding for CCAP), the German Research Foundation (DFG grant SFB454, TP B11) and the University of Konstanz * Corresponding author.

E-mail addresses: john.day@sams.ac.uk, jgd@sams.ac.uk (J.G. Day).

1 Current address: B CUBE - Center for Molecular Bioengineering, Technische Universität Dresden, Arnoldstr. 18, 01307 Dresden, Germany.
}

models" [14]. For diatoms, the complete genome sequences of two "model" diatoms have been published: Thalassiosira pseudonana [2] and Phaeodactylum tricornutum [4]. However, the number of po tential models needed to reflect the taxonomic, ecological and functional diversity of diatoms greatly exceeds the current capac ity of Biological Resource Centres to sequence, conserve, maintain and supply them to the user community. Additionally, with fresh water diatoms in particular, a major constraint remains the irre versible shrinkage of their silica based frustule (shell/cell wall) on prolonged culture [7].

Cryopreservation, with its potential for long term conservation of biological resources, provides an invaluable tool to ensure the biosecurity and genotypic stability of model diatom taxa. To date, a number of key marine model algae including both T. pseudonana and P. tricornutum, as well as the multicellular brown model alga Ectocarpus siliculosus, have been successfully cryopreserved using robust methodologies $[8,16]$. In contrast to marine diatoms, fresh water strains have proven problematic to cryopreserve and, to date, only moderate levels of success in cryopreservation of a small number of planktonic strains have been reported [22].

This study aimed to investigate the potential of using cryopres ervation to conserve freshwater benthic diatoms, employing the ecologically important taxon Planothidium frequentissimum, which has been reported to be one of the most common constituents of the benthic algal flora in streams and rivers [17], as a model for the future, more widespread, application of the approach. 


\section{Materials and methods}

\section{Organism and culture regime}

P. frequentissimum was isolated from an epilithic photoautotro phic biofilm sampled in the littoral zone of Lake Constance, Ger many. The strain was cultured in flat bottom polystyrene tissue culture flasks with vented lids in freshwater DM medium [1], at $18^{\circ} \mathrm{C}$. Cells were illuminated by cool white fluorescent lamps (OS RAM GmbH, Germany) with a photon flux density of $40 \mu \mathrm{mol} \mathrm{m}^{-2} \mathrm{~s}^{-1}$ at the surface of the culture flask under a 16:8 h light:dark regime. Stock cultures were maintained at $8{ }^{\circ} \mathrm{C}$ and sub cultured with one incubation cycle to the late log phase/stationary phase every 6 months using aseptic microbiological techniques.

\section{Generation of axenic benthic diatom cultures}

Axenic, bacteria free cultures were achieved by short term antibiotic treatment ( 3 days) with $\beta$ lactam antibiotics (ampicillin $100 \mu \mathrm{g} \mathrm{ml}^{-1}$, penicillin $100 \mu \mathrm{g} \mathrm{ml}^{-1}$, piperacillin $100 \mu \mathrm{g} \mathrm{ml}^{-1}$, ticarcillin $40 \mu \mathrm{g} \mathrm{ml}^{-1}$ ) and the $\beta$ lactamase inhibitor tazobactam $\left(20 \mu \mathrm{g} \mathrm{ml}^{-1}\right.$ ) (Sigma Aldrich, Germany). Cells were washed in a sin gle centrifugation step (10 min, 1000g), concentrated tenfold and spray plated on solid DM medium containing $1.2 \%(\mathrm{w} / \mathrm{v})$ agar (Bac to agar, Difco, UK). Liquid cultures were inoculated with colonies derived from single cells.

\section{Cryopreservation protocols employed}

In common with other benthic diatoms, $P$. frequentissimum forms aggregates if insufficient surface area is available for the attachment of all cells. In order to obtain reproducible homoge neous liquid cultures; uniform, flat biofilms were generated by removing non attached cells one day after inoculation of a fresh tissue culture flask via a washing step. In the late exponential growth phase, i.e. after incubation for two weeks, biofilms were suspended with sterile cell scrapers (Sarstedt, Germany). To avoid clumping, cell suspensions were used immediately after harvest. Prior to cryopreservation, diatom cell suspensions of either $4 \times 10^{5}$, or $8 \times 10^{5}$ cells $\mathrm{ml}^{-1}$, were treated with $5 \%(\mathrm{v} / \mathrm{v}$ ) dimethyl sulfoxide $\left(\mathrm{Me}_{2} \mathrm{SO}\right)$ and incubated at room temperature for $10 \mathrm{~min}$. Cryopreservation was performed in a controlled rate cooler (Kryo 3603.3 , Planer, UK) using a cooling rate of $-1{ }^{\circ} \mathrm{C} \mathrm{min}^{-1}$ from $20^{\circ} \mathrm{C}$ to $-40^{\circ} \mathrm{C}$ with automated ice seeding at $-5^{\circ} \mathrm{C}$, a $15 \mathrm{~min}$ "dwell" at $-40^{\circ} \mathrm{C}$ and a final plunge into liquid nitrogen. Alterna tively, a passive cooler (Biocision, USA) was used, according to manufacturer's instructions, with a pre determined cooling rate of $-1{ }^{\circ} \mathrm{C} \mathrm{min}^{-1}$, with no additional ice seeding/ice nucleation step and a final plunge of the samples into liquid nitrogen $1.5 \mathrm{~h}$ after the passive freezer unit had been placed in a $-80^{\circ} \mathrm{C}$ freezer. Samples were subsequently stored in liquid phase liquid nitrogen until required.

\section{Recovery procedure}

To test for viability, six vials were removed from cryostorage, transferred to the laboratory in liquid nitrogen and either warmed slowly to $0^{\circ} \mathrm{C}$ at room temperature $\left(20^{\circ} \mathrm{C}\right)$ in air, or more quickly to $0^{\circ} \mathrm{C}$ in a pre warmed temperature controlled water bath set to $40{ }^{\circ} \mathrm{C}$. Immediately after melting of all the ice, triplicate cryovials were diluted with the same volume of fresh medium $\left(2.5 \% \mathrm{Me}_{2} \mathrm{SO}\right.$ final concentration) and stored either at $8^{\circ} \mathrm{C}$ or at $18^{\circ} \mathrm{C}$, in the dark for 4 or 7 days. Further vials were transferred to a laminar flow cabinet, where $10 \mathrm{ml}$ liquid cultures in $25 \mathrm{~cm}^{2}$ flat bottom tissue culture flasks were inoculated in triplicates with $500 \mu \mathrm{l}$ of thawed culture. This resulted in a 20 fold dilution of the $\mathrm{Me}_{2} \mathrm{SO}$ to $0.25 \%(\mathrm{v} /$ $\mathrm{v})$. In regrowth experiments, $1 \mathrm{ml}$ inocula were used resulting in $0.5 \%(\mathrm{v} / \mathrm{v}) \mathrm{Me}_{2} \mathrm{SO}$ in DM. Cultures were incubated for 4 or 7 days at $18{ }^{\circ} \mathrm{C}$ either in the dark, at low light (photon flux of $38 \mu \mathrm{mol}$ photons $\mathrm{m}^{-2} \mathrm{~s}^{-1}$ ), or high light (photon flux of $40100 \mu \mathrm{mol}$ pho tons $\mathrm{m}^{-2} \mathrm{~s}^{-1}$ ). In later regrowth experiments, cultures were incu bated at $16{ }^{\circ} \mathrm{C}$ under analogous light regimes.

\section{Microscopy}

The effects of cryopreservation and post cryopreservation treat ments, as well as the recovery of diatom cells, were observed under the microscope using an Olympus BX51 epifluorescence micro scope equipped with phase contrast and DIC optics. Microscopical analysis of membrane integrity and viability was performed by neutral red staining $\left(1 \mu \mathrm{g} \mathrm{ml}^{-1}\right)$ under bright field microscopy and fluorescence microscopy of cells stained with $1.2 \mu \mathrm{M}$ carbo xyflorescein diacetate succinimidyl ester (CFSE), respectively. Chlorophyll autofluorescence and CFSE fluorescence were detected using mirror unit UMWSG2 (Olympus, Japan) and the filter set 41020 (Chroma Technology Corp, USA). Images were acquired with a Zeiss AxioCam MRc camera and analysed with the Axiovision software (version 4.9, Zeiss, Germany).

\section{Viability assessment of diatom cells using CFSE staining}

Cell viability was assessed by flow cytometry (see below) employing the non cytotoxic fluorescent vital stain CFSE that al lows discrimination between viable and non viable cells [19]. After incubation, biofilms of $10 \mathrm{ml}$ cultures $\left(25 \mathrm{~cm}^{2}\right.$ surface area) were suspended with a sterile cell scraper, pipetted and concentrated by centrifugation at $1000 \mathrm{~g}$ for $20 \mathrm{~min}$. The supernatant was dis carded and the pellet re suspended to a final volume of $2 \mathrm{ml}$. Ali quots of cell suspensions $(1 \mathrm{ml})$ were used for viability staining with $1.2 \mu \mathrm{M}$ CFSE ( $0.6 \mathrm{mM}$ Stock in $\left.10 \%(\mathrm{v} / \mathrm{v}) \mathrm{Me}_{2} \mathrm{SO}\right)$ and $1 \mathrm{ml}$ cell suspensions were used as inocula to assay regrowth. Alternatively, thawed, non diluted samples were used. After incubation for 10 min all samples were assessed by flow cytometry.

\section{Flow cytometry}

Post thaw cell viability was assessed using a FACSort flow cytometer (Becton Dickinson, UK) set to trigger on side scatter. The parameters measured were $90{ }^{\circ} \mathrm{C}$ side scatter (SSC), green CFSE fluorescence at $519 \mathrm{~nm}$ (FL1) and red chlorophyll autofluores cence at $695 \mathrm{~nm}$ (FL3). Fluorescein isothiocyanate labeled green fluorescent reference beads (Becton Dickinson, UK) with $2 \mu \mathrm{m}$ diameter were used as an internal standard and added to the sam ples immediately before they were processed. Viable cells, those capable of metabolizing CFSE, were detected by green fluorescence. Total cell numbers were measured via side scatter and chlorophyll autofluorescence.

The bead suspension was diluted with ultra pure water and fil tered through a $2 \mu \mathrm{m}$ polycarbonate filter (Nucleopore, GE, USA). Bead numbers were determined using fluorescence microscopy of beads on a polycarbonate track edge membrane (Nucleopore, GE, USA). The FACS was calibrated with fluorescent beads for test ing of forward and side scatter, and fluorescence FL1, FL2, FL3 (Becton Dickinson, Calibrate 3). Photomultiplier voltages were set at $350 \mathrm{~V}$ for SSC and $500 \mathrm{~V}$ for the fluorescence detector. The threshold parameter for FL1 was set at 69. For each sample, events were counted for $1 \mathrm{~min}$, equaling a count of approximately 1600 fluorescent beads. The standard deviation between counted bead numbers in different data sets was between $4 \%$ and $13 \%$. Exponen tially growing viable cells were used as a positive control for each set of samples analysed. Plating of the control culture on solid 
medium was performed to confirm $100 \%$ viability levels of un treated samples. Cell viability was calculated by comparing a re gion on a dot plot with FL1 plotted against FL3 with the total number of cells detected (Suppl. Fig. S1). A region on the dot plots defined by size, chlorophyll autofluorescence and metabolic activ ity of a viable control was compared with the total number of cells larger than $4 \mu \mathrm{m}$ showing high chlorophyll autofluorescence. For each cryobiological condition tested three biological replicates were measured.

\section{Regrowth experiments}

To test for regrowth, thawed diatom cells were treated as in via bility assessment experiments. After 7 days, tissue culture flasks were transferred to standard cultivation conditions and incubated for 3 to 4 weeks at $16^{\circ} \mathrm{C}$ under a $16: 8 \mathrm{~h}$ light:dark regime with a light level of $40 \mu \mathrm{mol}$ photons $\mathrm{m}^{-2} \mathrm{~s}^{-1}$. The flasks were visually checked for regrowth of the benthic adherent diatoms.

\section{Statistical analyses}

The data were compared statistically using Kruskal Wallis One Way ANOVA on Ranks followed pairwise multiple comparison by the Tukey Test. For pairwise comparisons, $t$ tests were performed. All analyses were performed with the Sigma Plot software, version 11.0 (Systat Software, USA). For all statistical analyses, significance was inferred at $p \leqslant 0.05$.

\section{Results}

Previous attempts by the authors to cryopreserve the freshwa ter diatom $P$. frequentissimum using standard algal protocols have proven unsuccessful, with no recovery/regrowth observed (Suppl. Table 3). Thawed cultures consisted mainly of white, bleached cells after one week of incubation under standard light conditions (40 $100 \mu \mathrm{mol}$ photons $\mathrm{m}^{-2} \mathrm{~s}^{-1}$ ), therefore we tested different post thawing light conditions.

Assessment of cell viability by CFSE fluorescence vital staining and flow cytometry

Epifluorescence microscopy of diatom cells stained with CFSE immediately after thawing of plunge frozen samples, indicated that non viable cells, including some of those with obviously rup tured cell membranes, could still produce an intense signal (Fig. 1A). Therefore the cells were incubated for additional 4 7 days, which allowed dying cells to lose their metabolic capabili ties prior to staining and assessment of cell viability by flow cytometry. After this period, the CFSE fluorescence signal of non viable cells was not detectable by epifluorescence microscopy (Fig. 2C) and lowered in flow cytometry (Fig. 2D). Flow cytometry further revealed that the intensity of chlorophyll fluorescence of non viable cells was lower than that of samples with viable cells
(Fig. 2D and Q); differences that were not detectable via epifluores cence microscopy (Fig. 2B, F, K, O).

\section{Damage to $P$. frequentissimum cells during cryopreservation}

Plunge freezing exponential phase $P$. frequentissimum cells in li quid nitrogen without any cryoprotectant invariably resulted in cell death. This treatment caused gross ultrastructural damage and staining with neutral red and bright field microscopy revealed that non viable cells had lost their membrane integrity. Neutral red stained control samples, where viable cells had intact organ elles with neutral to acidic $\mathrm{pH}$, were stained red and distinct from the surrounding medium (Fig. 1B), whilst frozen/thawed cells with disrupted organelles appeared yellow/brown (Fig. 1C). Further more, cryoinjuries resulted in an unstructured cell interior and a high number of intracellular vesicles, presumably resulting from disrupted cell organelles (Fig. 1C). After one week of incubation, the cells from thawed $P$. frequentissimum samples had completely bleached, indicating oxidation of both photosynthetic and photo protective pigments (Fig. 2A).

Impact of light regime on the viability of cryopreserved cells after thawing

Post thaw viability of $P$. frequentissimum was significantly en hanced ( $p<0.001, n=12$ ) when thawed cells were incubated un der lower light intensities, or in the dark for 47 days, rather than under normal cultivation conditions (Fig. 3). When subjected to moderate to high light intensities used for standard cultivation (40 $100 \mu \mathrm{mol}$ photons $\mathrm{m}^{-2} \mathrm{~s}^{-1}$ ), most cells bleached and died $(0.4 \pm 0.5 \%$ viable cells, Fig. $2 A)$. No CFSE stained cells were de tected by microscopy and very low numbers of viable cells by flow cytometry (Fig. 2C and D). Recovery under lower light levels (3 $8 \mu \mathrm{mol}$ photons $\mathrm{m}^{-2} \mathrm{~s}^{-1}$ ) resulted in increased levels of post thaw viability $(4.5 \pm 2.1 \%$ ) (Fig. 3F). The highest post thaw viability levels were observed for samples that had been incubated in complete darkness for 47 days ( $59 \pm 8.3 \%$ ) (Fig. $3 \mathrm{H}$ ). Additionally, post thaw viability levels were significantly enhanced when cultures of high er density $(2 \times)$ had been cryopreserved and after thawing had been incubated in the dark without transfer to tissue culture flasks $(p \leqslant 0.042$, paired $t$ test) (Figs 3 and 4 ).

Impact of the thawing rate, post thaw incubation temperature and cryoprotectant

Flow cytometry measurements indicated that incubation of dia tom cells at a lower temperature $\left(8^{\circ} \mathrm{C}\right)$ after thawing resulted, in most cases, in slightly increased viability levels compared to sam ples incubated at $18^{\circ} \mathrm{C}$ ( Fig. 4) $(p<0.05$ ). On examining individual cells by epifluorescence microscopy this effect was more pro nounced as a stronger fluorescence signal was observed from CFSE treated cells incubated at $8^{\circ} \mathrm{C}$ in the dark (Fig. 2P), although in re growth assays the highest growth levels were observed at $18^{\circ} \mathrm{C}$ after 47 days of incubation in the dark (Suppl. Fig. S2 and Table S1).
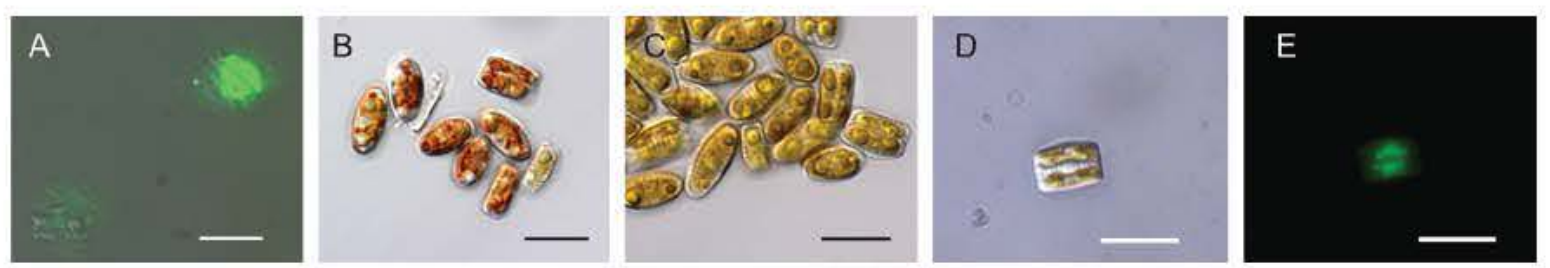

Fig. 1. Microscopy of Planothidium frequentissimum. (A) False positive CFSE stained, ruptured cells (stained immediately after thawing). (B) Neutral red stained untreated control cells (organelles discrete); (C) Neutral red stained plunge-frozen sample (organelles disrupted and cell interior stained in yellow indicating severe damage to cellular membranes); (D) Intact, dividing cell; (E) CFSE fluorescence of intact, dividing cell. 


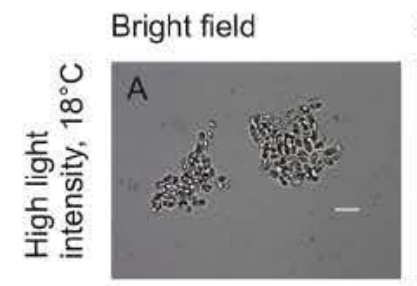

Chl. a
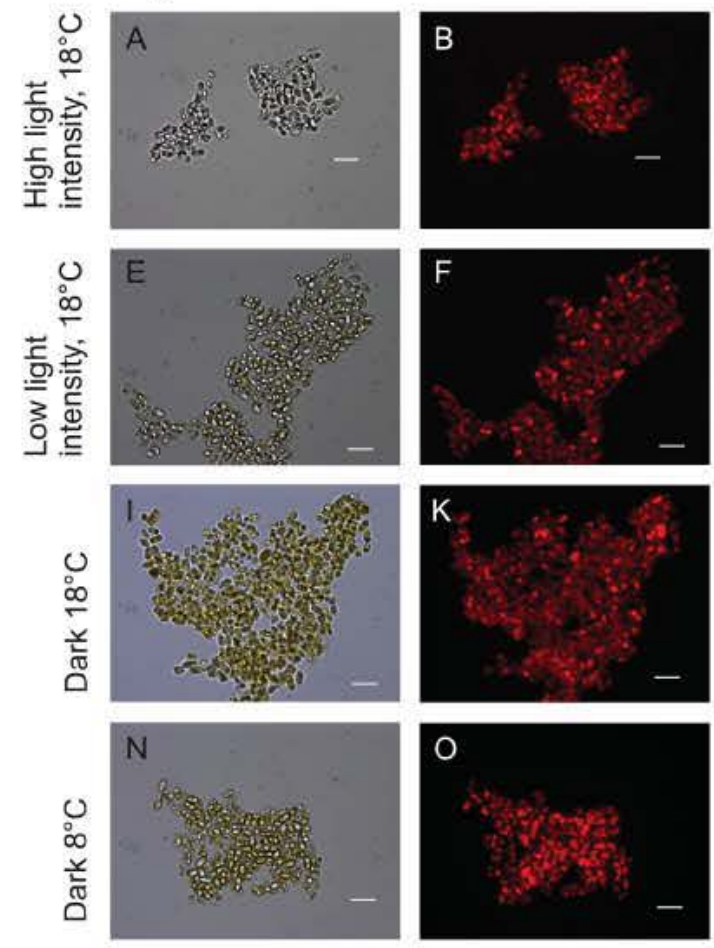
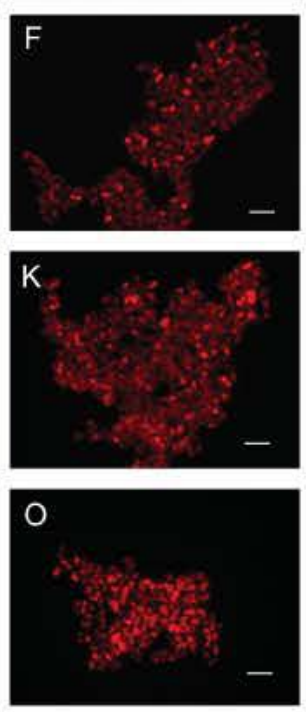

CFSE
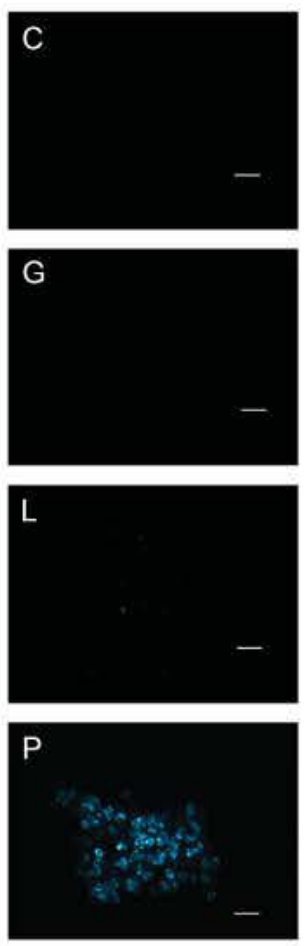
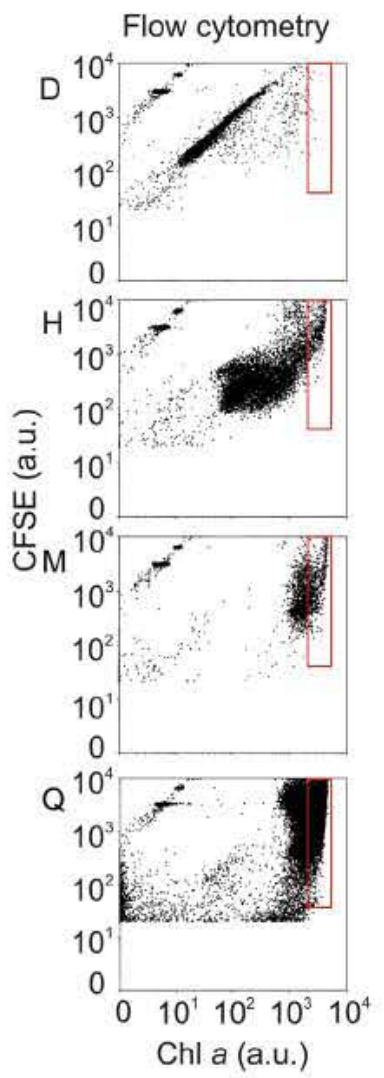

Fig. 2. Influence of light levels and temperature on the post-thaw viability of cryopreserved Planothidium frequentissimum. (A-D) Cells incubated under standard light conditions; (E-H) under low light intensity; (I-M): in the dark at $18^{\circ} \mathrm{C} ;(\mathrm{N}-\mathrm{Q})$ in the dark at $8{ }^{\circ} \mathrm{C},(\mathrm{D}, \mathrm{H}, \mathrm{M}, \mathrm{Q})$ : dot plot of viability assessment. Dots indicating viable cells are surrounded by the red box. (all scale bars $20 \mu \mathrm{m}$ ).

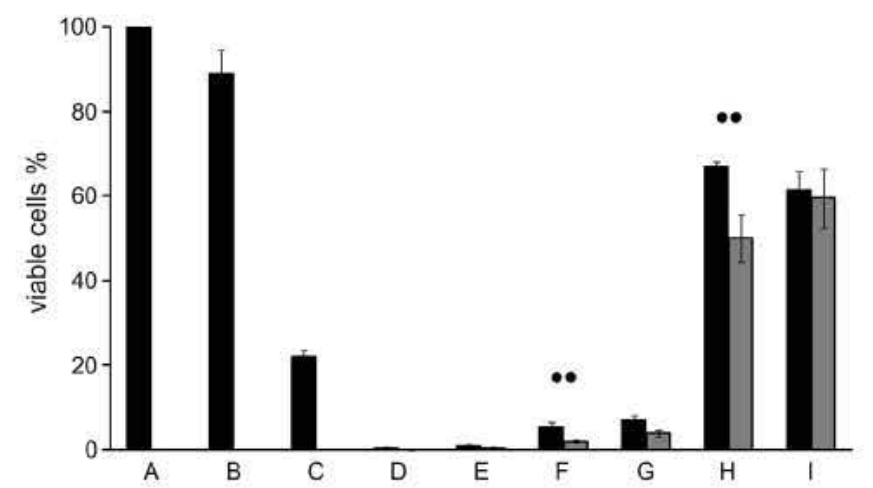

Fig. 3. Post-thaw viability of $P$. frequentissimum incubated in flat-bottom tissue culture flasks (in medium including $0.25 \% \mathrm{Me}_{2} \mathrm{SO}$ ). Black bars: double normal cell density inoculated, grey bars: normal concentration. (A) Control cells kept under standard light conditions; (B) under low light; (C) in the dark for four days; (D) incubated under standard light conditions thawed at $40^{\circ} \mathrm{C}$, or (E) $20^{\circ} \mathrm{C}$; (F) incubated under low light conditions thawed at $40^{\circ} \mathrm{C}$, or $(\mathrm{G}) 20^{\circ} \mathrm{C} ;(\mathrm{H})$ incubated in the dark and thawed at $40^{\circ} \mathrm{C}$, or (I) $20^{\circ} \mathrm{C}$. Dots: significant increase of post-thaw viability by double concentrated cell suspensions $(p<0.039)$.

On comparing slow and fast warming/thawing rates, no obvious enhancement in post thaw viability was observed (Figs 3 and 4). In growth assays, $P$. frequentissimum tolerated $\mathrm{Me}_{2} \mathrm{SO}$ at concentra tions up to $2.5 \%(\mathrm{v} / \mathrm{v})$ (Suppl. Table S2). At this concentration, non frozen cell cultures were still able to grow actively after two weeks, while at concentrations from 5 to $10 \%(v / v)$ cells did not di vide, but still appeared brownish in color indicating stability of

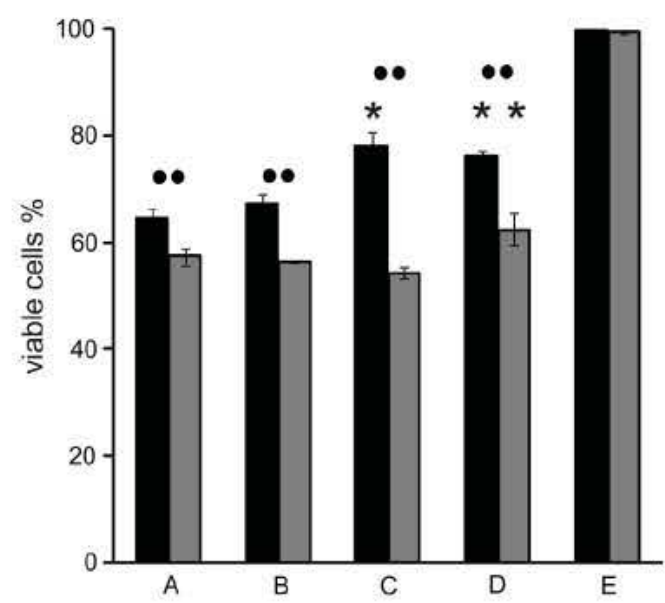

Fig. 4. Post-thaw viability of $P$. frequentissimum incubated in cryovials $\left(2.5 \% \mathrm{Me}_{2} \mathrm{SO}\right)$ in the dark for four days at 8 or $18^{\circ} \mathrm{C}$ compared to control cells grown under standard conditions. Black bars: double concentrated cell suspensions, grey bars: normal cell suspensions. (A) Thawed at $20^{\circ} \mathrm{C}$; incubated at $18^{\circ} \mathrm{C}$; (B) thawed at $40^{\circ} \mathrm{C}$, incubated at $18^{\circ} \mathrm{C}$; (C) thawed at $20^{\circ} \mathrm{C}$ incubated at $8{ }^{\circ} \mathrm{C}$; (D) thawed at $40^{\circ} \mathrm{C}$ incubated at $8{ }^{\circ} \mathrm{C}$; (E) control cell culture incubated under standard light conditions. Dots: significantly higher viability after cryopreservation of double normal concentration cell suspensions $(p<0.042)$. Star: significantly higher viability after incubation at $8^{\circ} \mathrm{C}$ instead of $18^{\circ} \mathrm{C}(p<0.048)$.

intracellular fucoxanthine and other photosynthetic pigments. At $\mathrm{Me}_{2} \mathrm{SO}$ concentrations of $20 \%(\mathrm{v} / \mathrm{v})$ cells appeared white and bleached (data not shown). In parallel experiments, $5 \%(v / v)$ meth anol also proved to be a suitably non toxic cryoprotectant. 
Regrowth assays

Regrowth assays in tissue culture flasks undertaken in repeated independent experiments demonstrated the capacity of post thaw, positively CFSE stained, cultures to regrow. After a 7 day initial dark phase and subsequent incubation of thawed diatoms under standard environmental regimes cells successfully divided, form ing clumps, making it impossible to assess cell densities using flow cytometry. It was noted that the trends observed were similar to the flow cytometer experiments, i.e. the highest viability/most ra pid increase in surface coverage by algal cells was obtained for samples incubated in the dark, or under low light after thawing.

\section{Discussion}

Although cryopreservation is a tool widely adopted by many freshwater algal collections [8], some major groups of algae includ ing most freshwater diatoms have not been successfully cryopre served by standard methods. Our results indicate that in some cases apparent recalcitrance can be overcome by optimizing the recovery phase, particularly by avoiding treatments with the po tential to induce photooxidative stress. Efforts to expand the range of algal taxa that can be cryopreserved have followed three strate gies: on going empirical development of conventional methods/ application of standard methods to new taxa; attempts to under stand why and when cryoinjury occurs during the cryopreserva tion process (with the objective of improving the methodology); and thirdly alternative vitrification based methods $[16,19,6]$. The focus of this study was based on the first two approaches, namely minor adaptation of a standard approach taking into consideration the potentially injurious effects of rewarming and optimizing the conditions for a successful post thaw recovery. In order to evaluate the efficacy of protocol developments, a sensitive, robust viability assessment method was required. This was achieved by vital stain ing with CFSE in combination with flow cytometry.

\section{Viability assessment}

Benthic, colonial clumping organisms are particularly problem atic to enumerate and considerable efforts have been made to de velop a robust method to assess the growth of benthic photoautotrophic microorganisms [6]. Although a suspension could be routinely produced as a starter culture for experimenta tion, because of the adherent growth habit of $P$. frequentissimum, it was not considered practicable to use a growth based viability assessment approach, such as colony forming on agar. Instead we found vital staining, growth observation after transfer to fresh medium and flow cytometry facilitated analysis to be useful tools to verify cell viability. Due to the low survival rates, measurements of the respiration rate, or PAM measurements of photosynthesis efficiency were impracticable.

In this study, CFSE was employed as a vital stain as the ester bond of the non fluorescent CFSE derivative is cleaved enzymati cally inside viable cells resulting in the fluorescing derivative; this approach has previously been successfully employed for the mar ine diatom T. pseudonana [23]. Compared to the vital stain fluores cein diacetate (FDA), used in previous algal studies [13], the higher stability of CFSE in aqueous solutions resulted in less background signal. Our observation that staining of the algal cells directly after thawing may result in false positives (Fig. 1A), presumably due to residual enzyme activity in non viable cells, has been described previously when using FDA staining to assess algal post cryo via bility [8]. An incubation period of four days prior to CFSE staining was sufficient to eliminate these false positives, as cell lysis and apoptosis after fatal injury may take several days for some algae (Day, unpublished observations).

\section{Enhancement of post cryopreservation viability}

Most standard cryopreservation protocols that have been ap plied to algae involve a one step warming procedure, generally in a $40^{\circ} \mathrm{C}$ water bath [8]. For sensitive materials, rewarming of cryopreserved samples may usually require optimisation as small innocuous ice crystals are capable of growing to a size that may cause injury in algae if warmed too slowly [10]. Similarly, relaxa tion of glasses on rewarming can fracture fragile and particularly rigid cell structures or they can devitrify and form ice if they are rewarmed too slowly [3]. In this study it might have been antici pated that slow warming would have been less satisfactory than faster warming, as previously suggested for marine diatoms (Sex ton, National Center for Marine Algae and Microbiota, pers. comm.). However, we could not find obvious advantages, or disad vantages, on utilising a slower warming protocol (Figs 3 and 4). This suggested that intracellular ice formation was not a major fac tor in the previously observed failure of the basic protocol when applied to benthic diatoms (Suppl. Table S3).

Initial studies demonstrated that the highly penetrating cryo protectants methanol and $\mathrm{Me}_{2} \mathrm{SO}$ appeared most effective, whereas using glycerol did not result in viable cultures and, furthermore, was more likely to support the growth of bacterial contaminants that in some cases overgrew diatom cultures with impaired viabil ity (Suppl. Table 3). In some algae with impermeable cell walls, including Haematococcus pluvialis aplanospores, the duration of exposure to the cryoprotectant may correlate with post thaw sur vival [10]. In this study there was no evidence to substantiate this, but most benthic diatoms are surrounded by cell surface polysac charides that may play a significant role in the penetration effi ciency of the cryoprotectant.

In some standard algal cryopreservation protocols a period of incubation in the dark, post warming, has been advised [8], and a beneficial effect of short incubation periods in the dark, or at low light, post thaw has been reported $[18,15]$. This procedure prevents the algae from initiating photosynthetic activity, thus avoiding the possibility of photo oxidatively induced stress. It has previously been reported that photosynthetic capacity can be significantly re duced in the cryo sensitive alga Euglena gracilis by both chilling and freezing induced damage [11]. Furthermore, structural and func tional damage to chloroplasts by low temperatures and freezing has been observed in both algae and higher plants $[10,15]$ and these injuries may be associated with free radical production, resulting from metabolic uncoupling and impaired quenching mechanisms $[11,9]$. In this study, light microscopy of thawed diatom cells re vealed that cryoinjury caused disruption of organelle membranes (Fig. 1C). Enzyme activity in thawed cells was initially retained, as evidenced by the capacity of obviously dead cells to give a CFSE sig nal (Fig. 1A), but this capacity was lost within $24 \mathrm{~h}$. It was observed that diatom cells that had died during cryopreservation, after incu bation in the light, appeared "bleached" white, or light green, rather than yellow/brown (Fig. 2A and Fig. 1D), as has previously been ob served for the related heterokont brown alga E. siliculosus [16]. This bleaching may have been initiated by reactive oxygen species (ROS), resulting from damaged photosystems, impaired induction of non photochemical quenching (NPQ) and lower amounts of ROS scavenging enzymes, resulting in oxidation of chlorophyll mol ecules and pigments due to ultrastructural and biochemical injuries sustained during the cryopreservation procedure [9]. In a previous study it was demonstrated that ROS induced injury could be reduced in algae, thus enhancing post cryopreservation viability levels, by the incorporation of antioxidants [11]. Additionally, it has been demonstrated that the freeze tolerant alga $H$. pluvialis is 
capable of a more coordinated biochemical defense to ROS than the cryo sensitive alga E. gracilis [12]. It may be speculated that the capacity of $P$. frequentissimum to recover from sub lethal injuries, induced by cryopreservation, were significantly enhanced by removing the potentially injurious effects of uncoupled photosyn thetic activity and photooxidative stress.

Incubating presumably damaged cells at $8{ }^{\circ} \mathrm{C}$ instead of $18{ }^{\circ} \mathrm{C}$ resulted in higher levels of post thaw viability (Figs 3 and 4). It was considered that reduced metabolic activity prevented exacer bation of cryo induced damage, thus allowing the cells to repair membrane associated damage. This in turn resulted in significantly $(p<0.048)$ improved viability levels (Fig. 3 ).

It was observed that cryopreservation of dense diatoms cultures resulted in higher post thaw viability than those with lower cell densities (Figs 3 and 4). This might be due to a possible self shad ing effect reducing the light "hitting" individual cells. In this con text the growth habit of this benthic diatom, i.e. its tendency to grow in biofilms or aggregates may play a role, by self shading of cells in the colony. This would indicate that cell aggregates instead of suspended cells might be the better choice for cryopreservation; however, in order to reproducibly culture sufficient amounts of cells in a comparable physiological state and because methanol/ $\mathrm{Me}_{2} \mathrm{SO}$ uptake may be strongly hindered by the biofilm Extracellu lar Polymeric Substances (EPS), we think that using suspended cells is essential to warrant a continuous quality of the cells and reproducible freezing/thawing efficiencies. Interestingly, algal cell densities of cultures used for cryopreservation may in some cases affect post cryopreservation viability negatively; for instance cryo preservation of dense Chlamydomonas reinhardtii cultures resulted in a reduction of post thaw viability [5]. This alga did not survive cryopreservation with high viability unless the culture density, at the time of freezing, was $\sim 2.5 \times 10^{6}$ cells ml $^{-1}$ or less [5]. This finding was explained as being due to water soluble intracellular toxins that may be released, presumably from lysing cells, on cryo preservation [5]. This does not appear to be a wide spread phe nomenon as in the CCAP collection (www.ccap.ac.uk) standard policy is to cryopreserve dense cultures, thus minimizing the time required to regenerate a healthy culture to dispatch to customers.

In regrowth assays performed in tissue culture flasks the same trends were observed as for samples maintained in the cryo vials after thawing: highest viability was obtained for samples incu bated in the dark, or in low light (Figs 3 and 4; Suppl. Table S1, Suppl. Fig. S3). An obvious criticism of incorporating an additional storage step is that the cells remain exposed to elevated $\mathrm{Me}_{2} \mathrm{SO}$ levels $(0.25$ or $2.5 \%)$ throughout the storage period; however, on testing $\mathrm{Me}_{2} \mathrm{SO}$ had no obvious toxicity/inhibitory effect on cell growth to P. frequentissimum below 2.5\% (v/v) (Suppl. Table S2). Although $\mathrm{Me}_{2} \mathrm{SO}$ may be toxic at high concentrations, it may con tribute to a reduction of photooxidative stress due to its antioxi dant properties [24].

To our knowledge, this is the first study reporting a significant $(p<0.001)$ increase in post thaw viability of freshwater diatoms by improving the post cryopreservation steps of the protocol. Additionally, preliminary work undertaken indicates that the pro tocol developed may be successfully employed to cryopreserve a second freshwater diatom, Achnanthidium minutissimum. In previ ous experiments on benthic (Suppl. Table S3) and planktonic fresh water diatoms [22], thawed cells were incubated at a light level of $\sim 40 \mu \mathrm{mol}$ photons $\mathrm{m}^{-2} \mathrm{~s}^{-1}$, without a preliminary dark phase, resulting in no, or poor, post thaw viability. By modifying estab lished thawing protocols and applying alternative recovery re gimes an effective protocol has been developed for $P$. frequentissimum. This work indicates that this approach has the po tential to successfully cryopreserve algae, particularly for freshwa ter diatoms, previously thought to be recalcitrant, or for which standard methods have proven ineffective.

\section{Acknowledgments}

This work was supported by the European Commission (ASSEMBLE, Integrated Infrastructures Initiative, grant agreement no. 227799), the UK Natural Environment Research Council (Na tional Capability funding for CCAP), the German Research Founda tion (DFG grant SFB454, TP B11) and the University of Konstanz. We thank Annette Ramsperger and Cecilia Rad Menendez for their support during lab work, Elaine Mitchell for her support with the flow cytometer, as well as Miriam Windler and Doris Ballert for providing Achnanthidium minutissimum cultures. We further acknowledge the help of Marina Potapova for her help with the identification of Planothidium frequentissimum.

\section{References}

[1] R. Andersen, J. Berges, P. Harrison, M. Watanabe, Recipes for Freshwater and Seawater Media, Algal culturing techniques. Elsevier, Amsterdam, 2005. 429-538.

[2] E.V. Armbrust, J.A. Berges, C. Bowler, B.R. Green, D. Martinez, et al., The genome of the diatom Thalassiosira pseudonana: ecology, evolution, and metabolism, Science 306 (2004) 79-86.

[3] E.E. Benson, Cryopreservation Theory, in: B.M. Reed (Ed.), Plant Cryopreservation: A Practical Guide, Springer Press, Germany, 2008, pp. 15-32.

[4] C. Bowler, A.E. Allen, J.H. Badger, J. Grimwood, K. Jabbari, et al., The Phaeodactylum genome reveals the evolutionary history of diatom genomes, Nature 456 (2008) 239-244.

[5] J.J. Brand, K.R. Diller, Application and theory of algal cryopreservation, Nova Hedwigia 79 (2004) 175-189.

[6] M. Buhmann, P.G. Kroth, D. Schleheck, Photoautotrophic-heterotrophic biofilm communities: a laboratory incubator designed for growing axenic diatoms and bacteria in defined mixed-species biofilms, Environ. Microbiol. Rep. 4 (2011) 133-140.

[7] N.A. Davidovich, Cell-division time in the diatom Haslea subagnita (PR-LAVR) Market et Kar (Bacillariophta) at different stages of the life-cycle, Soviet Plant Physiol. 39 (1992) 386-390.

[8] J.G. Day, JJ. Brand, Cryopreservation Methods for Maintaining Microalga cultures, in: R. Andersen (Ed.), Algal culturing techniques, Elsevier Academic Press, 2005, pp. 165-188

[9] N. Domingues, A.R. Matos, J.M. da Silva, P. Cartaxana, Response of the diatom Phaeodactylum tricornutum to photooxidative stress resulting from high light exposure, PloS one 7 (2012) e38162.

[10] R.A. Fleck, The Assessment of Cell Damage and Recovery in Cryopreserved Freshwater Protists, Univ. Abertay Dundee, Dundee, 1998.

[11] R.A. Fleck, E.E. Benson, D.H. Bremner, J.G. Day, Studies of free radical-mediated cryoinjury in the unicellular green alga Euglena gracilis using a non-destructive hydroxyl radical assay: a novel approach for developing protistan cryopreservation strategies, Free Radic. Res. 32 (2000) 157-170.

[12] R.A. Fleck, E.E. Benson, D.H. Bremner, J.G. Day, A comparative study of antioxidant protection in cryopreserved unicellular algae Euglena gracilis and Haematococcus pluvialis, CryoLetters 24 (2003) 213-228.

[13] R.A. Fleck, R.W. Pickup, J.G. Day, E.E. Benson, Characterisation of cryoinjury in Euglena gracilis using flow-cytometry and cryomicroscopy, Cryobiology 52 (2006) 261-268.

[14] C.M.M. Gachon, J.G. Day, C.N. Campbell, T. Proschold, R.J. Saxon, et al., The culture collection of algae and protozoa (CCAP): a biological resource for protistan genomics, Gene 406 (2007) 51-57.

[15] K. Harding, J. Müller, M. Lorenz, H. Timmerman, T. Friedl, et al., Deployment of the encapsulation/dehydration protocol to cryopreserve microalgae held at The Sammlung von Algenkulturen, Universität Göttingen, Germany, CryoLetters 29 (2008) 15-20.

[16] S. Heesch, J.G. Day, T. Yamagishi, H. Kawai, D.G. Müller, et al., Cryopreservation of the Model Alga Ectocarpus (Phaeophyceae), CryoLetters 33 (2012) 327-336.

[17] T. Johnson, K. Hermann, S. Spaulding, B. Beyea, C. Theel, et al., An ecological assessment of USEPA Region 8 streams and rivers, Environmental Protection Agency, Denver, CO., USA, 2009.

[18] A. Lukesova, P. Hrouzek, K. Harding, E.E. Benson, J.G. Day, Deployment of the encapsulation/dehydration protocol to cryopreserve diverse microalgae held at the Institute of Soil Biology, Academy of Sciences of the Czech Republic Cryoletters 29 (2008) 21-26.

[19] A.B. Lyons, C.R. Parish, Determination of lymphocyte division by flow cytometry, J. Immunol. Methods 171 (1994) 131-137.

[20] D. Mann, S.J.M. Droop, 3. Biodiversity, biogeography and conservation of diatoms, Hydrobiologia 336 (1996) 19-32. 
[21] M.P. Mansour, D.M.F. Frampton, P.D. Nichols, J.K. Volkman, S.I. Blackburn, Lipid and fatty acid yield of nine stationary-phase microalgae: applications and unusual C-24-C-28 polyunsaturated fatty acids, J. Appl. Phycol. 17 (2005) 287300

[22] M. McLellan, Cryopreservation of diatoms, Diatom Res. 4 (1989) 301-318.

[23] Rad Menendez, C., Phenotypic and genotypic characterization of Thalassiosira pseudonana (Bacillariophyta) strains, Univ Aberdeen, Aberdeen, 2011.
[24] J.S. Miller, D.G. Cornwell, Role of cryoprotective agents as hydroxy radical scavengers, Cryobiology 15 (1978) 585-588.

[25] F.E. Round, R.M. Crawford, D.G. Mann, Diatoms: Biology and Morphology of the Genera, Cambridge University Press, 1990.

[26] J. Volkman, S. Jeffrey, P. Nichols, G. Rogers, C. Garland, Fatty acid and lipid composition of 10 species of microalgae used in mariculture, J. Exp. Mar. Biol. Ecol. 128 (1989) 219-240. 